\title{
HUBUNGAN ANTARA KADAR LIPID DARAH DENGAN TIPE STROKE
}

\author{
Bahrudin, Mochamad*
}

\begin{abstract}
ABSTRAK
Latar Belakang: Stroke merupakan keadaaan emergensi dan penyebab kecacatan nomor satu dan kematian nomor dua di dunia, yang dibagi menjadi dua jenis yaitu stroke iskemik dan stroke perdarahan. Tinggi dan rendabnya kadar kolesterol darah dibubungkan dengan tipe stroke.

Tujuan: untuk mengetahui bubungan antara kadar lipid darah dengan tipe stroke.

Metode: Desain penelitian adalah observasional analitik dengan pendekatan cross sectional, dengan pengambilan data secara consecutive sampling. Variabel yang diteliti adalah pasien stroke infark dan perdarahan, dibubungkan dengan kadar lipid darah (kolesterol,ratioLDL/ HDL, $m$ dan trigliserida). Analisis data menggunakan statistik uji chi square dengan tingkat kebermaknaan á=0.05.

Hasil: Didapatkan sampel 112 pasien, stroke infark (58\%) dan stroke perdarahan 52\%, Kejadian stroke sebagian besar terjadi setelah umur 40 tabun (> 90\%), wanita lebih sering terkena stroke baik pada stroke infark maupun perdarahan. Kadar kolesterol darah tinggi (kolesterol >160) lebih banyak dijumpai pada stroke infark (65,9\%) dan kadar kolesterol rendah (kolesterol <160) lebih sering dijumpai pada stroke perdarahan (66,7\%) dengan analisa Chi-square signifikan $P=0,003$. Kadar ratio LDL/HDL rendab $(<3)$ lebih banyak dijumpai pada stroke perdaraban (51\%) dan kadar ratio LDL/HDL tinggi (>3) lebih banyak dijumpai pada stroke infark (65,1\%), dengan analisa Chi-square tidak signifikan $P=0,087$. Kadar trigliserida tinggi $(>200)$ maupun rendah $(<200)$ lebih banyak dijumpai pada stroke infark dengan $P=0.384$ tidak signifikan.
\end{abstract}

Kesimpulan: Ada bubungan antara kadar lipid darah (kolesterol) dengan tipe stroke. Kadar kolesterol tinggi merupakan faktor resiko terjadinya stroke infark dan kadar kolesterol rendah untuk stroke perdarahan.

Kata Kunci: kadar kolesterol darah, tipe stroke, stroke infark, stroke perdarahan.

\footnotetext{
* Bagian Ilmu Syaraf, Fakultas Kedokteran Universitas Mubammadiyah Malang.
} 


\section{ABSTRACT}

Background: Stroke is emergency and the number one cause of disability and second cause of mortality all over the world, that is classified into two types, which are infarct and hemorrbagic stroke. The level of cholesterol within blood circulation is associated to the development of the type of stroke.

Objective: The aim of this research was to investigate the correlation between blood lipid level and type of stroke.

Method: The research design was analytic observational with cross sectional approach and applied consecutive sampling technique to collect data. The studied variable here was infarc and haemorrbagic stroke patients, and then was correlated to blood cholesterol level, ratio LDL/HDL cholesterol, triglycerida. Chi square statistical test was utilized to analyze the data with significance level $a=0.05$.

Result: There were 112 patients as the eligible samples, which consisted of 58\% infarction and 52\% haemorrbagic stroke patients. Most documented age range of infarction stroke patients was after 40 years (>90\%). Most gender that was found among infarction and haemorrhagic stroke patients was female and so was found Infarction stroke patients most likely had higher bigh blood cholesterol level (>160) 65,9\% and haemorrbagic stroke patients most likely had higher low blood cholesterol level $(<160) 66,7 \%$. The derived result from Chi-square test was significance $(p)=0.003$. haemorrbagic stroke patients most likely had higher low ratio LDL/HDL level $(<3) 51 \%$ and Infarction stroke patients most likely had higher high ratio LDL/ HDL level (>3) 65,1\%. The derived result from Chi-square test was not significance $P=0,087$ and then infarction stroke patients most likely had higher high and low triglyceride level with $P=0.384$ not significance

Conclusion: there is a significant correlation between blood cholesterol level and stroke type. High cholesterol level is the risk factor of infarction stroke and low cholesterol level is haemorrbagic stroke.

Keywords: blood cholesterol level, stroke type, infarction stroke, baemorrhagic stroke.

\section{PENDAHULUAN}

\section{Latar Belakang}

Peningkatan usia harapan hidup yang didorong oleh keberhasilan pembangunan nasional akan cenderung meningkatkan terjadinya penyakit vaskular seperti stroke (Misbach et.al,2011). Stroke merupakan keadaaan emergensi, yang sekarang dikenal dengan serangan otak (brain attack). Oleh karena itu begitu mengalami serangan stroke, harus dengan segera meminta pertolongan kepada yang berkompeten dengan sarana yang memadai agar prognosis lebih baik (Indonesian Neurological Association, 2010).

Sampai saat ini stroke masih merupakan masalah besar, sekaligus tantangan di bidang kesehatan, karena stroke menduduki peringkat kedua setelah penyakit jantung atau ketiga setelah penyakit jantung dan kangker dalam urutan penyebab kematian (falluji,2012). Di Amerika stroke merupakan penyebab kematian nomor tiga dan terdapat 750.000 orang terserang stroke setiap tahunya dan 150.000 meninggal karena stroke tersebut (Davis, 2005). Data stroke di Indonesia menunjukkan kecenderungan peningkatan kasus stroke baik dalam hal kejadian, kecacatan, maupun kematian. Angka kematian berdasarkan umur adalah sebesar 15,9\% (umur 45-55 tahun) dan 26,8\% (umur 55-64tahun), dan 23,5\% (umur $>65$ tahun).kejadian stroke sebesar 51,6/100.000 penduduk, dan kecacatan $1,6 \%, 4,3 \%$ semakin memberat, penderita laki-laki lebih banyak dari perempuan, dan profil berdasarkan umur dibawah 45 tahun sebesar 11,8\%, umur 45-64 tahun sebesar $54,2 \%$ dan umur diatas 65 tahun sebesar 33,5\% (Misbach et.al,2011).

Stroke dapat menyerang usia bayi, anakanak, usia produktif, hingga usia lanjut (Arbour,2005) yang mana usia produktif lebih banyak sehingga akan berdampak dan berpotensi menimbulkan masalah baru dalam pembangunan kesehatan secara keseluruhan (Misbach, 2007).

Stroke dibagi menjadi dua jenis yaitu stroke iskemik dan stroke perdarahan. Pada stroke iskemik, aliran darah ke otak terhenti karena atherosclerosis dan hampir sebagian besar pasien $(83 \%)$ mengalami stroke jenis ini. Pada stroke perdarahan, pembuluh darah pecah sehingga menghambat aliran darah yang normal dan darah merembes ke dalam suatu daerah di otak dan menimbulkan kompresi ke jaringan otak sekitarnya. Hampir 70\% kasus stroke 
perdarahan terjadi pada penderita hipertensi (Auryn, 2007).

Dislipidemia adalah kelainan metabolisme lipid yang ditandai dengan peningkatan maupun penurunan fraksi lipid dalam plasma. (Assman et al., 2004). Dalam proses terjadinya aterosklerosis semuanya memiliki peranan yang penting dan sangat erat kaitannya satu sama lain, (Kopins and Lowenstein, 2010). Dislipidemia dapat menyebabkan terjadinya akumulasi lipid dalam pembuluh darah yang mengakibatkan perubahan struktural dan fungsi endotel. LDL adalah lipoprotein pembawa kolesterol terbesar dalam plasma. LDL sangat peka terhadap reaksi oksidasi (El-Melegy et al, 2001). Efek aterogenik LDL didapatkan dari komponen LDL yang teroksidasi (Packard and Libby, 2008). ox-LDL (LDL yang teroksidasi) menyebabkan aktivasi endotel dan perubahan dalam karakteristiknya (Fruchart and Lille, 2003).

Hiperkolesterolemia sendiri diyakini mengganggu fungsi endotel dengan meningkatkan produksi radikal bebas oksigen. Radikal ini menonaktifkan oksida nitrat, yaitu faktor endothelial relaksing utama. Apabila terjadi hiperlipidemia kronis, lipoprotein tertimbun dalam lapisan intima di tempat meningkatnya permeabilitas endotel. Pemajanan terhada radikal bebas dalam sel endotel dinding arteri menyebabkan terjadinya oksidasi LDL-C yang berperan dan mempercepat timbulnya plak ateroma. Oksidasi LDL-C diperkuat oleh kadar HDL-C yang rendah, diabetes mellitus, defisiensi esterogen, hipertensi dan adanya riwayat merokok. Deposisi lipid dan jaringan ikat mengubah bercak lemak menjadi ateroma lemak fibrosa matur. Rupturnya plak menyebabkan inti bagian dalam plak terpajan LDL-C yang teroksidasi dan meningkatnya perlekatan elemen sel, termasuk trombosit. Akhirnya deposisi lemak dan jaringan ikat mengubah fibrosa menjadi ateroma yang dapat mengalami perdarahan, ulserasi, kalsifikasi, atau trombosis, dan menyebabkan infark serebri. (Price, 2005).

Hipokolesterol serum dapat menyebabkan terjadinya kerusakan sel-sel otot pada tunika media pembuluh darah dan terjadinya insudasi plasma darah serta histolisis sehingga terbentuknya fibrinoid. Fibrinoid ini akan tertimbun dalam tunika intima dan akhirnya nekrosis, yang menyebabkan tunika kaku dan rapuh. Pada keadaan normo kolesterol maupun hipokolesterol tidak terbentuknya plak ateroslerotik. Hipokolesterol serum secara tidak langsung dapat memperberat kerapuhan pembuluh darah dan menimbulkan perdarahan kecil-kecil serta memperberat stroke perdarahan intraserebral, sehingga meningkatkan mortalitas maupun morbiditas. (Irribaren, et al, 2002; Lee et al, 2002).

Berdasar uraian tersebut, peneliti ingin membuktikan adanya hubungan antara kadar lipid dalam darah dengan tipe stroke yang terjadi. Diharapkan dengan penelitian ini dapat membantu untuk mengetahui kecenderungan tipe stroke yang terjadi dengan memperhatikan hasil pemeriksaan kadar lipid (lipid profile) darah sehingga dapat dilakukan tindakan pencegahan dan pengobatan.

\section{Metode Penelitian}

Jenis penelitian ini adalah penelitian observasional analitik dengan rancangan yang digunakan adalah Cross Sectional Study. Penelitian dilakukan di

RSU Haji Surabaya, RSUD Jombang, RSUD Kediri, dan RS Muhammadiyah Lamongan mulai bulan April 2013 sampai dengan Agustus 2013.

Seluruh penderita stroke yang datang ke Instalasi Rawat Darurat dan ruang perawatan Saraf RSU Haji Surabaya, RSUD Jombang, RSUD Kediri, dan RS Muhammadiyah Lamongan diambil sebagai sampel. Sampel dipilih dengan cara consecutive sampling pada penderita stroke akut yang memenuhi kriteria inklusi dan eksklusi.

\section{Kriteria inklusi}

- Semua pasien stroke (perdarahan dan iskemik) akut semua umur, laki-laki dan perempuan yang ditegakkan berdasarkan pemeriksaan neurologis dan didukung oleh alat bantu CTScan otak.

- Semua pasien stroke yang diperiksa profil lipid darah.

\section{Kriteria eksklusi}

- Pasien stroke dengan hipertensi (tensi > 200/100 mmHg) 
Ukuran sampel dihitung menurut rumus sampel tunggal dengan menggunakan ketepatan absolut (Sastroasmoro, Ismael 1995).

$\mathrm{n}=\frac{Z \alpha^{2} P Q}{d^{2}} \quad$ Catatan : $\mathrm{Q}=(1-\mathrm{P})$

Dimana ,

Zá = Nilai baku normal tingkat kemaknaan berdasarkan nilai á yang telah ditentukan peneliti (á $=0,05)$ è1,96

$\mathrm{P}=$ Proporsi sensitivitas atau spesifitas uji diagnostik yang akan dicari (sumber pustaka) è sensitivitas = $95 \%$, spesifitas $=90 \%$

$\mathrm{d}=$ Tingkat ketepatan absolut yang dikehendaki yang ditetapkan oleh peneliti

sekitar $\pm 10 \%$ è 0,10

$$
\begin{aligned}
\mathrm{n} 1=\frac{1.96^{2} \times 0,95 \times 0,05}{0,10^{2}} & =\frac{3,8416 \times 0,00475}{0,01} \\
& =18 \\
\mathrm{n} 2=\frac{1,96^{2} \times 0,90 \times 0,10}{0,10^{2}} & =\frac{3,8416 \times 0,09}{0,01} \\
& =34
\end{aligned}
$$

Dengan demikian diperlukan minimal sampel sejumlah $(18+34)=52$

Data akan diolah dan dianalisa dalam bentuk tabel kemudian untuk mendapatkan data analitik dilakukan uji korelasi chi square menggunakan program SPSS for windows versi 12.

\section{Hasil Penelitian}

Penelitian ini bertujuan untuk mengetahui hubungan antara kadar lipid darah dengan tipe stroke yang dilakukan Instalasi Rawat Darurat dan ruang perawatan Saraf RSU Haji Surabaya, RSUD Jombang, RSUD Kediri, dan RS Muhammadiyah Lamongan. Pada penelitian ini didapatkan sampel 112 orang pasien stroke.

Data pasien stroke yang diperoleh tersebut dikelompokkan sebagai berikut : kadar ratio LDL/HDL, kadar kolesterol, kadar trigliserida dan hasil CT-Scan perdarahan atau infark. Kemudian diolah sesuai dengan tujuan penelitian tersebut diatas.

\begin{tabular}{|c|c|c|c|}
\hline \multirow[t]{2}{*}{ V ariabe 1} & \multicolumn{3}{|c|}{ Frekuensi pada Tipe Stroke } \\
\hline & Infark & Perdarahan & $\mathbf{P}$ \\
\hline Stroke & $65(58 \%)$ & $47(42 \%)$ & \\
\hline \multicolumn{4}{|l|}{ U sia (tahun): } \\
\hline $30-40$ & $3(33.3 \%)$ & $6(66,7 \%)$ & \\
\hline $41-50$ & $15(60 \%)$ & $10(40 \%)$ & \\
\hline $51-60$ & $20(60,6 \%)$ & $13(39,4 \%)$ & \\
\hline $61-70$ & $15(53,6 \%)$ & $13(46,4 \%)$ & \\
\hline $71-80$ & $7(58,3 \%)$ & $5(41,7 \%)$ & \\
\hline $81-90$ & $3(100 \%)$ & $0(0 \%)$ & \\
\hline $91-100$ & $2(100 \%)$ & $0(0 \%)$ & \\
\hline \multicolumn{4}{|l|}{ Jenis Kelamin: } \\
\hline Laki-laki & $30(57.7 \%)$ & $22(42.3 \%)$ & \\
\hline Perempuan & $35(58.3 \%)$ & $25(41.7 \%)$ & \\
\hline \multicolumn{4}{|l|}{ Kadar Kolesterol Total: } \\
\hline Tinggi (>160 mg/dl) & $56(65,9 \%)$ & $29(34,1 \%)$ & 0,003 \\
\hline Rendah (=160 mg/dl) & $9(33,3 \%)$ & $18(66,7 \%)$ & \\
\hline \multicolumn{4}{|l|}{ Kadar ratio LDL/HDL: } \\
\hline Tinggi $(>3)$ & $41(65,1 \%)$ & $22(34,9)$ & 0.087 \\
\hline Rendah $(<3)$ & $24(49 \%)$ & $25(51 \%)$ & \\
\hline \multicolumn{4}{|l|}{ Kadar Triglis erida } \\
\hline Tinggi $\quad(>200)$ & $9(69,2 \%)$ & $4(30,8 \%)$ & 0.384 \\
\hline Rendah $(<200)$ & $56(56,6 \%)$ & $43(43,4)$ & \\
\hline \multicolumn{4}{|l|}{$\begin{array}{l}\text { Rasio Prevalensi (RP): } \\
\text { Kolesterol tinggi dengan in fark: } 1.954 \\
\text { Kolesterol tinggi dengan perdarahan: } \\
0.506 \\
\text { Kolesterol rendah dengan infark: } 0.506 \\
\text { Kolesterol rendah dengan perdarahan: } \\
1.954\end{array}$} \\
\hline
\end{tabular}

Tabel 3.1. Karakteristik Sampel dan Analisa Hasil Penelitian 
Karakteristik sampel (tabel 3.1) menunjukkan : dari 112 pasien, kejadian stroke lebih banyak stroke infark (65 pasien (58\%) dibanding stroke perdarahan. Kejadian stroke berdasarkan umur pada stroke infark sebagian besar terjadi setelah umur 40 tahun (kurang lebih $90 \%$ ), demikian juga dengan stroke perdarahan, dan berdasarkan jenis kelamin laki - laki (57,7\%) maupun perempuan $(58,3 \%)$ kejadian stroke terbanyak pada stroke infark dibanding stroke perdarahan, sedangkan berdasarkan jenis stroke wanita lebih sering terkena stroke dibanding laki laki baik pada stroke infark maupun perdarahan.

Kadar kolesterol darah tinggi (kolesterol $>160$ ) lebih banyak dijumpai pada stroke infark $(65,9 \%)$ dibanding stroke perdarahan dan kadar kolesterol rendah (kolesterol <160) lebih sering dijumpai pada stroke perdarahan $(66,7 \%)$. Perbedaan ini kemudian dianalisa dengan menggunakan uji chisquare dan didapatkan hasil yang signifikan $\mathrm{P}=$ 0,003. Kadar ratio LDL/HDL rendah $(<3)$ lebih banyak dijumpai pada stroke perdarahan (51\%) dibanding stroke infark dan kadar ratio LDL/ HDL tinggi $(>3)$ lebih banyak dijumpai pada stroke infark $(65,1 \%)$, kemudian kami analisa dengan menggunakan uji chi-square dan didapatkan hasil yang mendekati signifikan $\mathrm{P}=0,087$. Kadar trigliserida tinggi $(>200)$ maupun rendah $(<200)$ lebih banyak dijumpai pada stroke infark dan setelah dianalisa dengan menggunakan uji chi-square dihasilkan hasil yang tidak signifikan ( $\mathrm{P}=0.384)$.

Dari hasil penghitungan rasio prevalensi, didapatkan rasio prevalensi antara kolesterol tinggi dengan stroke infark sebesar 1.954 dan kolesterol rendah dengan stroke perdarahan sebesar 1.054. Hal ini menunjukkan bahwa kolesterol yang tinggi merupakan faktor resiko terjadinya stroke infark dan kolesterol rendah merupakan faktor resiko terjadinya stroke perdarahan.

\section{Pembahasan}

Stroke adalah suatu sindroma yang ditandai dengan gangguan fungsi otak, fokal atau global, yang timbul mendadak, berlangsung lebih dari 24 jam atau berakhir dengan kematian tanpa penyebab yang jelas selain vascular (WHO). Jadi stroke adalah kelainan jaringan otak yang disebabkan oleh gangguan aliran darah. Stroke menyebabkan kehilangan fungsi otak yang diakibatkan oleh berhentinya suplai darah ke bagian otak. Ini adalah kulminasi penyakit serebrovaskular selama beberapa tahun. Stroke mempunyai banyak faktor resiko yang bisa diperbaiki antara lain hipertensi, penyakit kardiovaskular, kolesterol tinggi, obesitas, peningkatan hematokrit, Diabetes Mellitus (berkaitan dengan aterogenesis terakselerasi), kontrasepsi oral (khususnya dengan hipertensi, merokok, dan kadar estrogen tinggi), penyalahgunaan obat (kokain), dan konsumsi alkohol. Namun faktor resiko stroke yang tidak dapat dikendalikan adalah usia, jenis kelamin, ras, riwayat keluarga, dan riwayat stroke (Suzane Smeltzer, 2002, Davis, 2005).

Stroke infark atau iskemik menempati urutan terbanyak diantara jenis stroke. Hal ini berkaitan dengan pembentukan plak aterosklerosis yang merupakan faktor resiko terjadinya stroke, dimana akibat langsung dari plak aterosklerosis tersebut adalah sumbatan pembuluh darah sehingga terjadi iskemia jaringan dan terjadi stroke infark lebih cepat (Lamsudin (2002), Lumbantobing, 2004, Davis, 2005 Bahrudin, 2013). Pada penelitian ini juga mandapatkan hasil yang sama kejadian stroke infark lebih banyak dibanding stroke perdarahan (tabel 3.1).

Kejadian stroke labih banyak terjadi setelah umur 40 tahun karena pembentukan aterosklerosis kebanyakan dimulai pada usia diatas 40 tahun (Aminoff 2003, Misbach et.al,2011). Perjalanan pembentukan plak aterosklerosis ini mula- mula nampak sebagai garis lemak (fatty streak) pada usia 10 tahun ke bawah. Garis lemak ini mula-mula timbul pada aorta dan arteri koroner. Pada umur 20 tahun ke atas, garis lemak ini dapat tumbuh lebih progresif menjadi fibrous plaque yaitu suatu penonjolan jaringan kolagen dan sel-sel nekrosis. Lesi ini berwarna kelabu yang disebut ateroma. Plak fibrus ini timbul pada usia tiga puluh tahun dan pada usia 40 tahun, timbul lesi lebih kompleks dan timbul konsekuensi klinis seperti angina pektoris, infark miokard, dan sudden death. Stroke dapat menyerang semua usia, namun paling sering adalah usia diatas 50 tahun. Pada usia 50 tahun, tempattempat aterosklerotik sudah banyak dan tersebar secara difus pada pembuluh arterial serebral (Suzane Smeltzer 2002, Sidharta 2008). Pada penelitian ini mendukung peryataan diatas bahwa kejadian stroke terjadi lebih banyak setelah usia 40 tahun (tabel 3.1)

Pada penelitian ini pasien stroke lebih banyak terjadi pada wanita dibanding laki-laki namun dengan perbedaan yang tidak terlalu besar. 
Aterosklerosis lebih banyak diderita oleh kaum pria daripada wanita, karena faktor hormonal seperti estrogen melindungi wanita. Setelah menopause perbandingan wanita dan pria yang menderita penyakit aterosklerosis adalah sama (Aminoff 2003). Dalam hal ini, responden dalam penelitian ini lebih banyak yang berusia diatas 40 tahun, dimana itu merupakan usia menopause bagi wanita (Lisabeth, 2009) sehingga perbedaan jumlah pasien laki-laki dan perempuan tidak terlalu besar.

Kadar kolesterol darah tinggi (kolesterol $>160$ ) lebih banyak dijumpai pada stroke infark dibanding stroke perdarahan dan kadar kolesterol rendah (kolesterol <160) lebih sering dijumpai pada stroke perdarahan yang di analisa dengan uji chisquare dan didapatkan hasil yang signifikan $\mathrm{P}=$ 0,003. Kadar ratio LDL/HDL rendah $(<3)$ lebih banyak dijumpai pada stroke perdarahan dan kadar ratio LDL/HDL tinggi (>3) lebih banyak dijumpai pada stroke infark dengan nilai $\mathrm{P}=0,087$ yang mendekati signifikan. Faktor penyebab kadar kolesterol yang tinggi adalah faktor genetik, diet tinggi lemak, kelebihan berat badan, kurangnya aktivitas fisik, dan merokok. Hal ini dihubungkan dengan peningkatan resiko penyakit akibat gangguan pembuluh darah misalnya penyakit jantung koroner dan stroke (Suzane Smeltezer, 2002). Hiperkolesterol dapat memicu terjadinya aterosklerosis. Diawali dengan disfungsi endotel, LDL berlebih dalam pembuluh darah akan teroksidasi oleh radikal bebas. LDL teroksidasi tersebut memicu monosit untuk masuk ke dalam intima dan berubah menjadi makrofag. Makrofag akan memfagosit LDL dan menjadi sel busa yang akan menempel di dinding pembuluh darah dan terbentuklah aterosklerosis yang menyebabkan penyempitan lumen pembuluh darah dan menurunkan aliran darah otak sehingga sel otak mengalami iskemia (Adam 2007).

Hipokolesterol serum dapat menyebabkan terjadinya kerusakan sel otot pada tunika media pembuluh darah dan terjadi insudasi plasma darah serta histolisis sehingga terbentuk fibrinoid. Fibrinoi ini akan tertimbun dalam tunika intima dan akhirnya nekrosis, yang menyebabkan tunika kaku dan rapuh (Quick 2000). Hipokolesterol serum secara tidak langsung dapat memperberat kerapuhan pembuluh darah dan menimbulkan perdarahan (Lee 2002). Hipokolesterol serum dapat menjadi marker fragilitas kapiler (Permadi 2000).
Dari uji korelasi antara kadar kolesterol dan ratio LDL/HDL terdapat korelasi yang pasitif (lampiran ) artinya kadar kolesterol yang tinggi akan diikuti ratio LDL/HDL yang tinggi pula demikian juga sebaliknya. Oleh karena itu meskipun hasil analisa hubungan antara ratio LDL/HDL dengan tipe stroke tidak signifikan akan tetapi kecenderngan tiangginya kadar kolesterol dan tingginya ratio LDL/HDL adalah sama yaitu menngarah pada stroke infark. Hasil yang tidak signifikan ini kemungkinan disebabkan karena kelemahan dari penelitian ini yaitu tidak dapat memisahkan faktor resiko penyebab stroke lainnya selain kadar kolesterol darah dan hipertensi.

Selanjutnya dari tabel silang antara kadar kolesterol dengan tipe stroke dapat diketahui rasio prevalensi (RP) dan didapatkan hasil bahwa kadar kolesterol total yang tergolong tinggi merupakan faktor resiko terjadinya stroke infark. Sebaliknya, kadar kolesterol total yang tergolong rendah merupakan faktor resiko terjadinya stroke perdarahan.

Dari hasil penelitian diatas, sebagai klinisi kita dapat mengambil makna bahwa kita harus berhati-hati ketika memberikan obat-obatan anti kolesterol sebagai terapi prevensi pada pasca stroke infark. Semakin rendah kadar kolesterol akan labih baik sebagai proteksi stroke infark akan tetapi jangan lupa rendahnya kadar kolesterol dalam darah akan memicu terjadinya stroke perdarahan.

\section{Kesimpulan dan Saran}

\section{Kesimpulan}

1. Kadar kolesterol darah tinggi (kolesterol $>160)$ lebih banyak dijumpai pada stroke infark $(65,9 \%)$ dan kadar kolesterol rendah (kolesterol <160) lebih sering dijumpai pada stroke perdarahan $(66,7 \%)$.

2. Kadar ratio LDL/HDL rendah $(<3)$ lebih banyak dijumpai pada stroke perdarahan (51\%) dan kadar ratio LDL/HDL tinggi (>3) lebih banyak dijumpai pada stroke infark $(65,1 \%)$,

3. Kadar trigliserida tinggi (>200) maupun rendah $(<200)$ lebih banyak dijumpai pada stroke infark.

4. Terdapat hubungan yang signifikan antara kadar kolesterol dengan tipe stroke. Kadar kolesterol yang tinggi (>160) merupakan 
faktor resiko terjadinya stroke infark dan kadar kolesterol yang rendah $(<160)$ merupakan faktor resiko terjadinya stroke perdarahan.

\section{Saran}

1. Bagi Tenaga medis

Sebaiknya para tenaga medis dapat melakukan pencegahan terjadinya stroke, yang tejadi akibat kadar kolesterol darah, sehingga dengan penatalaksanaan yang adekuat diharapkan dapat mengurangi angka kesakitan dan kematian akibat stroke.

2. Bagi masyarakat

Masyarakat selalu waspada terhadap segala faktor resiko yang dapat meningkatkan terjadinya stroke, melalui pencegahan sejak dini dengan cara menerapkan gaya hidup sehat, dengan cara menurunkan berat badan berlebih, berolahraga secara teratur, banyak makan serat, konsumsi buah dan sayuran, berhenti merokok, dan mengikuti diet yang rendah lemak jenuh dan kolesterol. Sehingga resiko terjadinya stroke dapat ditekan seminimal mungkin dan dapat dilakukan pencegahan dan penatalaksanaan yang adekuat untuk mengurangi angka kesakitan dan kematian akibat stroke.

3. Bagi peneliti berikutnya

Sebaiknya dilakukan kembali penelitian serupa dengan metode yang lebih baik dengan mengendalikan faktor resiko stroke yang lain sehingga hubungan kadar kolesterol dengan tipe stroke benar-benar terjadi tanpa dipengaruhi factor resiko yang lain (perancu) 


\section{DAFTAR PUSTAKA}

Adam JMF, Soegondo S, Semiardji G, et al, 2006, Petunjuk Praktis Penatalaksanaan Dislipidemia, hal. 1, 5-6.

Adam, J.M.F 2007, Buku Ajar Ilmu Penyakit Dalam jilid III, FKUI, Jakarta hal. 865-870

Adam R.D. et al. 2002. Cerebrovascular Disease dalam Principles of Neurology.

Ahmed SH, Hu CJ, Paczynski, Hsu YH , 2001, Pathophysiology of Ischemic Injury, in Fisher M: Stroke Theraphy $2^{\text {nd }}$ ed, Butterworth Heinemann, Boston ; , 25-50

Alireza A , Tracey A . Matthew Brandon Maas, Joseph E, 2009, Ischemic Stroke: Pathophysiology and Principles of Localization, Neurology Volume 13, Part 1:1-14.

Allan H.Ropper, M.D, Robert H. Brown, D.Phil., M.D, 2005 : Cerebrovaskular Disease in Adams and Victors Principles of Neurology ${ }^{\text {sth }}$.ed. Mc Graw-Hill , Medical Publishing Division, New York : 660-727.

Amarenco P 2002, Hypercholesterolemia,Lipid Lowering Agents, and The Risk for Brain Infarction. In Neurology. Volume 57. america Academy of Neurology. France, pp. 1-7.

Aminoff MJ, Daroff RB, 2003, Encyclopedia of the Neurological Sciences, 8th ed, Elsevier Inc, California, pp. 651

Aminoff , MJ, Greenberg DA, Simon RP. 2005. Stroke, dalam Clinical Neurology 5th edition. USA: McGRAW-HILL hal. 289-292

Arbour Richard, Parker Frizzell Joan, March Karen, 2005, Acute Stroke: Pathophysiology, Diagnosis, and Treatment, AACN Advanced Critical Care ; 16 ; 4 ;421 - 440

Auryn, V.2008. Mengenal dan Memahami Stroke. Yogyakarta: Katahati, hal. 69-72.

Bart van der Worp H, van Gijn Jan, 2007, Acute Ischemic Stroke, N Engl J Med ; August 9 ; 357:572-579

Broderick Joseph P, Adams Harold P, Barsan William, 1999, Guidelines for the Management of Spontaneous Intracerebral Hemorrbage, , American Heart Association.

Brott Thomas, Bogousslavsky Julien, 2000, Treatment of Acute Ischemic Stroke, N Engl J Med; September 7; 343:710-722
Budiarto G, 2002 :Stroke and Hypertension dalam Pendidikan Kedokteran Berkelanjutan Update on Neurology, Surabaya.

Caplan L.R. 2000, Intracerebral Hemorrbage. In Stroke : A Clinical Approach. Third ed. Library of Congres Catalogis. USA, pp. 383-418.

Davis, Larry. King Molly K, Jessica L. Schultz, 2005, Disorders of The Cerebrovaskular Sistem in Fundamentals of Neurologic Disease, Demos Medical Publishing, Inc., 386 Park Avenue South, New York, New York ; 87-99

Davis, C., Fischer, J., Ley, K., Sarembock, I.J. 2003. The role of inflammation in vascular injury and repair. J Thromb Haemost. 1, pp. 16991709.

El-Melegy, N.T., Mohamed, N.A., Sayed, M.M. 2008. Oxidative modification of low-density lipoprotein in relation to dyslipidemia and oxidant status in children with steroid sensitive nephrotic syndrome. Pediatric Res. 63(4), pp. 404-409

Falluji Nezar, Abou-Chebl Alex, Rodriguez Castro Carlos E, Mukherjee Debabrata, 2012, Reperfusion Strategies for Acute Ischemic Stroke, Angiology 63(4) 289-296.

Feigin, V. 2007. Stroke, Panduan Bergambar Tentang Pencegahan dan Pemulihan Stroke. Jakarta: PT Buana Ilmu Populer hal 9-20

Fruchart, J.C. and Lille. 2003. In : Task Force Symposium. Scuol : International Task Force for Prevention Coronary Heart Disease.

Gilroy J, 2000, Basic Neurology $3^{\text {rd }}$ ed, McGrawHill, New York.

Guyton, AC. 2008. Metabolisme Lemak dalam Buku Ajar Fisiologi Kedokteran. Jakarta: EGC, hal. 281-283.

Harsono. 2005. Buku Ajar Neurologi Klinis. Yogyakarta: Gadjah Mada University Press hal 59-54

Indonesian Neurological Association, 2010, Advanced Neuro Critical Care Support, POKDI Neurointensif and Critical care PERDOSSI.

Iribarren C et al. 1996, Low Total Serum Cholesterol and Intra Cerebral Hemorrbagic Stroke: is The Association Confined to Elderlymen? Americam Heart Association.California : 1-14.

Islam MS, Maret 2004 : Pedoman Praktis Penatalaksanaan Stroke Iskemik Akut. Pendidikan kedokteran berkelanjutan. 
Jannis J , 2003 : Patofisiologi Stroke Iskemik, dalam simposium New paradigm secondary prevention of stroke and other atherothrombotic events, Surabaya

Japardi, I. 2002. Patofisiologi Stroke Iskemik Tromboemboli. Available from URL Produktif http://library.usu.ac.id/download/ fk/bedah.pdf diakses 10 Desember 2011.

Junaidi, I. 2007. Stroke A-Z. Jakarta: Buana Ilmu Populer hal 1-9

Kalim Harmani Prof. dr. Sp.JP, 2006, 18th Weekend Course on Cardiology (WECOC) Simposia Vol.6 No.4, viewed 5 Januari 2010 <http:/ /www.majalah-farmacia.com>.

Kopins, L. and Lowenstein, C. 2010. In the clinic dyslipidemia. Ann Intern Med. 153(3): ITC2-1ITC2-16.

Lamsudin, R. 2002. Algoritma Gadjah Mada, Penyusunan dan Validasi Untuk Membedakan Stroke Perdarahan Intraserebral dengan Stroke Iskemik Akut atau Stroke Iskemik in: Berkala Ilmu Kedokteran Vol. 28 No 4, hal 181-187

Lee S.H. et al. 2002, Low Concentration of Serum Total Cholesterol is Associated with Multifocal Signal loss lesions on Gradient Echomagnetic Resonance Imaging. America Heart Association. Korea, pp. 1-11.

Libby, P., Ridker, P.M., Hansson, G.K. 2009. Inflammation in atherosclerosis: from pathophysiology to practice. I Am Coll Cardiol. 54, pp. 2129-38.

Libby, P., Ridker, P.M., Maseri, A. 2002. Inflammation in atherosclerosis. Circulation. 105, pp. $1135-$ 1143.

Liebeskind, DS. 2011. Hemorrhagic Stroke in Emergency Medicine. Available from URL: http:// emedicine.medscape.com/article/1916662overview. diakses 11 Januari 2012

Lisabeth et al 2009, Age at Natural Menopause and Risk of Ischemic Stroke. America Heart Association. Texas, pp. 1-7.

Lumbantobing, S.M. 2004. Neurogeriatri. Jakarta: Balai Penerbit FKUI hal 93-104

Mayes, P. 2003. Metabolisme Lemak dalam Biokimia Harper. Jakarta: EGC hal 254-286

Misbach, J. 2007. Stroke Mengancam Usia. Available from URL Produktif.http// www.medicastore.com/med/index.php diakses 25 September 2011

Misbach J, Wendra A. 2003: Stroke in Indonesia, a first large prospective hospital based study of acute stroke in 28 hospitals in Indonesia.

Misbach Jusuf, Lamsudin Rusdi, Aliah Amiruddin, Basyirudin, Suroto et,al, 2011, Guideline Stroke tahun 2011, Pokdi Stroke Perhimpunan Dokter Spesialis Saraf Indonesia (PERDOSSI)

Murray, Robert K. 2003. Pengangkutan dan Penyimpanan Lipid. Dalam Biokimia Harper. Edisi 25. Jakarta: EGC hal 254-269.

Packard, R.R.S., Libby, P. 2008. Inflammation in atherosclerosis: from vascular biology to biomarker discovery and risk prediction. Clin Chem. 54(1), pp. 24-38.

Permadi,A. Suhan, D 2000, Peranan Kadar Kolesterol pada Kematian Stroke Perdarahan Intraserebral yang dirawat. Dalam Neurona. Vol.17. SMF. Ilmu Penyakit Saraf FK. UNPAD. RS.Dr. Hasan Sadikin, Bandung, hal. 29-33.

Price, S. A., Wilson, L. M. 2005. Patofisiologi Konsep Klinis Proses - Proses Penyakit. Edisi 6. Jakarta: EGC hal. 580-582, 585-588

Quick D.G. 1999, Low Cholesterol Level May Be Linked to Depression, Anxiety. Doctor's Guide Publising Limited. Duke University Medicine : 13.

Qureshi A et al, 2001, Spontaneous Intracerebral Hemorrhagic, The New England Journal of Medicine ; 344: 1450-1460

Rohkamm Reinhard, 2004, Stroke in Color Atlas of Neurology, Thieme, Stuttgart - New York ; 167-179.

R.J. Thurman, E.C. Jauch , 2002, Acute ischemic stroke: emergent evaluation and management, Emerg Med Clin N Am 20 : 609-630

Sacco Ralph L, Christoph Diener Hans, Yusuf Salim, Cotton Daniel, Stephanie Ôunpuu, et.al, 2008, Aspirin and Extended-Release Dipyridamole versus Clopidogrel for Recurrent Stroke, N Engl J Med; 359: September 18; 1238-1251

Sastroasmoro S, Ismail S. 1995. Dasar-Dasar Metodologi Penelitian Klinis.Jakarta. Bina Rupa Aksara. 


\section{$46 \quad$ Vol. 10 No. 1 Tahun 2014}

Shidarta, P. 2004. Neurologi Klinis dalam Praktek Umum. Jakarta: Dian Rakyat hal. 98-99

Shidarta P, 2008, Neurologi Klinis Dasar. Jakarta: Dian Rakyat, hal. 271

Simmons S. 2002. Low Cholesterol : OverLooked Health Risk. United Kingdom.

Simon RP et al. 1999 : Clinical Neurology. $4^{\text {th }}$ ed. Appleton \& Lange, Stamford, p. 300-304

Stephen M. Davis, Geoffrey A. Donnan, 2012, Secondary Prevention after Ischemic Stroke or Transient Ischemic Attack, N Engl J Med; 366 : 17 Mei :1914-1922

Sunardi. 2008. Computed Tomography Scan (CT Scan) dan Magnetic Resonance Imaging (MRI) pada Sistem Neurologis. Available from URL: http://nardinurses.files.wordpress.com/ 2008/01/konsep-ct-scan-mri.pdf diakses 10 Januari 2012.

Susilo H. 2000. Stroke: Pendekatan segi epidemiologi dan faktor resiko. Dalam : Simposium Stroke. Patofisiologi dan Penanganan Stroke. Suatu pendekatan baru di Era Millenium III.

Susilo H ,2002, Current Management of Hypertension: Focus on Stroke Prevention in "Current Management of Hypertension: Can ACE-inbibitors Position Replaced by Angiotension II Receptor Antagonist in The Future", Surabaya.

Underwood JCE. 2002. Patologi Umum dan Sistematik. Dalam Sistem Kardiovaskular. Edisi 2. Jakarta: EGC hal 326-332.

Vauthey C. et al. 2000, Better Out Come after Stroke with Higher Serum CholesterolLevel. In Neurology. Volume 54. American Academy of Neurology. Switzerland, pp. 1-6.

World Health Organization. 2008. Centralized Pan Asian Survey on the Undertreatment of hypercholesterolmeia. Available from URL http://who.int/research/en/ diakses 15 November 2011

Widjaya D, , 2002 : Perkembangan Mutakhir Patofisiologi Stroke Iskemik Dalam Pertemuan Ilmiah Regional (PIR) II PERDOSSI cabang Manado-Makassar.

Yano K et al. 2000, Serum Cholesterol dan Hemorrbagic Stroke in the Honolulu Heart Program. In Stroke. Vol. 20. American Heart Association. Hawai, pp. 1-7. 